\title{
Analysis of blood culture in a rat model of cecal ligation and puncture induced sepsis
}

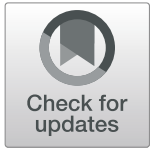

Prabakar Vaittinada Ayar ${ }^{1,2,3^{*}}$ (D) Hervé Jacquier ${ }^{3,4,5}$, Benjamin Deniau ${ }^{2,3,6}$, Feriel Azibani ${ }^{2,3}$, Alexandre Mebazaa ${ }^{2,3,6}$ and Alice Blet ${ }^{2,3,6}$

\begin{tabular}{l}
\hline *Correspondence: pvaittinada@ \\
gmail.com \\
${ }^{1}$ Emergency Department, Beaujon \\
Hospital, AP-HP, 100, Boulevard du \\
Général Leclerc, 92300 Clichy, \\
France \\
${ }^{2}$ INSERM UMR-S942 MASCOTT, Paris, \\
France \\
Full list of author information is \\
available at the end of the article
\end{tabular}

available at the end of the article
To the Editor,

Sepsis shows a high incidence and is associated with a high mortality [1, 2], and experimental studies are useful for a better understanding of sepsis and for identifying new therapies [3].

The cecal ligation and puncture (CLP) model is considered as the gold standard experiment for studying sepsis in animals. Recent guidelines recommend resuscitating animals after performing CLP including administration of fluid and chosen antimicrobials based on known pathogens. However, microbial identification is not a common practice in pre-clinical models of sepsis.

The aims of this original study were:

- To assess microbial situation in CLP-induced sepsis in the recent literature

- To document microbiology of blood cultures in rat CLP-induced sepsis performed in our lab.

\section{Keyword-based review}

The review was performed on PubMed using "CLP" and "rat" keywords for Englishwritten papers in 2018 and 2019 and also for "mouse" and "CLP." Bacteriological documentation and antimicrobial therapy were collected.

\section{CLP model in rats}

Sixteen Wistar male rats, from 9 to 12 weeks of age weighing 350 to $450 \mathrm{~g}$ were obtained from Janvier (St. Berthevin, France). CLP model was performed as previously described $[4,5]$. Septic shock was reached $16 \mathrm{~h}$ after induction by CLP, and blood samples were collected by jugular withdrawn. Culture and bacteriological analysis were done as previously described $[6,7]$.

\section{Keyword-based review revealed a few administrations of antibiotics in CLP models}

Our keyword-based review performed on PubMed resulted in 176 publications between 2018 and 2019 for rats. Among them, 22 (12.5\%) were excluded for a different

(c) The Author(s). 2020 Open Access This article is licensed under a Creative Commons Attribution 4.0 International License, which permits use, sharing, adaptation, distribution and reproduction in any medium or format, as long as you give appropriate credit to the original author(s) and the source, provide a link to the Creative Commons licence, and indicate if changes were made. The images or other third party material in this article are included in the article's Creative Commons licence, unless indicated otherwise in a credit line to the material. If material is not included in the article's Creative Commons licence and your intended use is not permitted by statutory regulation or exceeds the permitted use, you will need to obtain permission directly from the copyright holder. To view a copy of this licence, visit http://creativecommons.org/licenses/by/4.0/. 
Table 1 Blood culture analysis of 16 rats $16 \mathrm{~h}$ after CLP

\begin{tabular}{|c|c|c|c|}
\hline & & rat $n^{\circ}$ & $\mathrm{N}^{\circ}$ of occurrences \\
\hline & $\begin{array}{lllllllll}1 & 2 & 3 & 4 & 5 & 6 & 7 & 8 & 5\end{array}$ & $\begin{array}{llllllll}9 & 10 & 11 & 12 & 13 & 14 & 15 & 16 \\
\end{array}$ & \\
\hline Escherichia coli & & & 14 \\
\hline Enterococcus faecalis & & & 13 \\
\hline Enterobacter cloacae & & & 12 \\
\hline Staphylococcus aureus & & & 2 \\
\hline Streptococcus oralis & & & 1 \\
\hline Lactobacillus gasseri & & & 1 \\
\hline Lactobacillus murinus & & & 1 \\
\hline
\end{tabular}

meaning of CLP acronym. In only 15\% (23/154), antimicrobial therapy has been used, mostly (57\%) the third generation cephalosporin (ceftriaxone) (Table S1).

For mice, 59 (14.6\%) of 405 studies were excluded. In 18\% (62/346), antibiotics have been administered, mostly (47/62, 76\%) the carbapenem (imipenem/ertapenem) (Table S2).

However, none of the studies performed microbiological documentation before treatment.

\section{Blood culture analysis $\mathbf{1 6} \mathbf{h}$ after sepsis induction}

In 16 CLP rats, Escherichia coli 88\% (14/16), Enterococcus faecalis 81\% (13/16), and Enterobacter cloacae $75 \%(12 / 16)$ were the main pathogens found in blood cultures (Table 1). All bacteria exhibit a wild-type phenotype for antimicrobial agent susceptibility.

Our literature review about CLP-induced sepsis showed that antibiotherapy and bacteriological documentation was not reported in experimental models.

Blood cultures in our CLP model frequently identified 3 bacteria, in accordance with common polymicrobial infections in stercoral peritonitis in humans. Further, similar microbial profile (Enterobacteriaceae and Enterococci) was also found between our CLP model and human peritonitis [8].

By analyzing antimicrobial susceptibility testing, all bacteria exhibit a wild-type phenotype. Carbapenems definitely proved to be the most congruent antibiotics in our model. However, antimicrobial narrow spectrum therapy, including cotrimoxazole, seemed appropriate (Table 2).

To conclude, our literature search shows that antimicrobial therapy is not daily used in the treatment of CLP-induced sepsis, and when used, no bacterial identification is performed. Our data indicates that blood culture is readily available and may give a correct indication on which antimicrobial therapy to use in CLP-induced sepsis.

Table 2 In vitro susceptibility (minimal inhibitory concentration $(\mu \mathrm{g} / \mathrm{mL})$ ) of the organisms identified in the blood culture in our CLP rats $(n=16)$ to antimicrobial drugs

\begin{tabular}{llll}
\hline & E. coli & E. cloacae & E. faecalis \\
\hline Imipenem & 0.38 & 0.38 & 1 \\
Tazocillin & 2 & 2 & 2 \\
Cotrimoxazole & 0.6 & 0.125 & 0.016 \\
Levofloxacin & 0.06 & 0.06 & 1 \\
\hline
\end{tabular}




\section{Supplementary information}

Supplementary information accompanies this paper at https://doi.org/10.1186/s40635-020-00310-6.

Additional file 1: Figure S1. Peritoneal fluid culture analysis of 16 rats 16 hours after CLP

Additional file 2: Table S1. Probabilistic antimicrobial therapy used in rat CLP models in the literature published in 2018 and 2019

Additional file 3: Table S2. Probabilistic antimicrobial therapy used in mouse CLP models in the literature published in 2018 and 2019

\section{Abbreviation}

CLP: Cecal ligation and puncture

\section{Acknowledgements}

Not applicable

\section{Authors' contributions}

PVA and AB designed the experiments. PVA and BD performed the experiments and collected the blood samples. PVA and $\mathrm{HJ}$ performed the bacteriological analysis. All authors discussed the data, drafted or revised critically the manuscript for important intellectual content, and approved the final manuscript.

\section{Funding}

None

\section{Availability of data and materials}

The datasets used and/or analyzed during the current study are available from the corresponding author on reasonable request.

\section{Ethics approval and consent to participate}

All experiments using laboratory animals were conducted in our lab in accordance with the National and European Institutes of Health guidelines and were approved by the local animal research ethics committee (Lariboisière-Villemin, Paris, France) (APAFIS\#9385-2016113016181432 v4).

\section{Consent for publication}

Not applicable

\section{Competing interests}

All other authors declare that they have no competing interests.

\section{Author details}

${ }^{1}$ Emergency Department, Beaujon Hospital, AP-HP, 100, Boulevard du Général Leclerc, 92300 Clichy, France. ${ }^{2}$ INSERM UMR-S942 MASCOTT, Paris, France. ${ }^{3}$ University of Paris, Paris, France. ${ }^{4}$ Laboratory of Microbiology, Department of Infectious Agents, Lariboisière Hospital, AP-HP, Paris, France. ${ }^{5}$ INSERM, IAME, UMR 1137, Paris, France. ${ }^{6} \mathrm{GH}$ St-Louis-Lariboisière, Department of Anesthesiology, Critical Care and Burn Unit, St-Louis Hospital, AP-HP, Paris, France.

Received: 7 February 2020 Accepted: 25 May 2020

Published online: 05 June 2020

\section{References}

1. Fleischmann C, Scherag A, Adhikari NKJ et al (2016) Assessment of global incidence and mortality of hospital-treated sepsis. Current Estimates and Limitations. Am J Respir Crit Care Med 193:259-272 https://doi.org/10.1164/rccm.201504$07810 \mathrm{C}$

2. Rudd KE, Johnson SC, Agesa KM, et al (2020) Global, regional, and national sepsis incidence and mortality, 1990-2017: analysis for the Global Burden of Disease Study. Lancet 395:200-211. https://doi.org/10.1016/ S0140-6736(19)32989-7

3. Osuchowski MF, Ayala A, Bahrami S et al (2018) Minimum quality threshold in pre-clinical sepsis studies (MQTiPSS): an international expert consensus initiative for improvement of animal modeling in sepsis. Intensive Care Med Exp 6:26 https://doi.org/10.1186/s40635-018-0189-y

4. Rittirsch D, Huber-Lang MS, Flierl MA, Ward PA (2009) Immunodesign of experimental sepsis by cecal ligation and puncture. Nat Protoc 4:31-36 https://doi.org/10.1038/nprot.2008.214

5. Blet A, Deniau B, Geven C et al (2019) Adrecizumab, a non-neutralizing anti-adrenomedullin antibody, improves haemodynamics and attenuates myocardial oxidative stress in septic rats. Intensive Care Med Exp 7:25 https://doi.org/ $10.1186 / s 40635-019-0255-0$

6. Amarsy-Guerle R, Mougari F, Jacquier $\mathrm{H}$ et al (2015) High medical impact of implementing the new polymeric beadbased BacT/ALERT ${ }^{\circledR}$ FAPlus and FNPlus blood culture bottles in standard care. Eur J Clin Microbiol Infect Dis 34:10311037 https://doi.org/10.1007/s10096-015-2319-8 
7. EUCAST The European Committee on Antimicrobial Susceptibility Testing. Breakpoint tables for interpretation of MICs and zone diameters, version 9.0, 2019. http://www.eucast.org/fileadmin/src/media/PDFs/EUCAST_files/ Breakpoint_tables/v_9.0_Breakpoint_Tables.pdf. Accessed 27 Nov 2019

8. Montravers P, Lepape A, Dubreuil L et al (2009) Clinical and microbiological profiles of community-acquired and nosocomial intra-abdominal infections: results of the French prospective, observational EBIIA study. J Antimicrob Chemother 63:785-794 https://doi.org/10.1093/jac/dkp005

\section{Publisher's Note}

Springer Nature remains neutral with regard to jurisdictional claims in published maps and institutional affiliations.

Submit your manuscript to a SpringerOpen ${ }^{\odot}$ journal and benefit from:

- Convenient online submission

- Rigorous peer review

- Open access: articles freely available online

- High visibility within the field

- Retaining the copyright to your article 